\title{
Etik İklim, İşe Yabancılaşma ve Örgütsel Özdeşleşmenin İşten Ayrılma Niyeti Üzerindeki Etkisi: Otel İşletmelerinde Bir Araştırma
}

The Effect of Ethical Climate, Work Alienation and Organizational Identification on Turnover Intention: A Research on Hotel Establishments

\author{
Muharrem TUNA*, Murat YEŞiLTAŞ ${ }^{* *}$ \\ *Doç. Dr., Gazi Üniversitesi, Turizm Fakültesi, 06830, Gölbaşı, Ankara. \\ E-posta: muharrem@gazi.edu.tr \\ ** Yrd. Doç. Dr., Mehmet Akif Ersoy Üniversitesi, Turizm İşletmeciliği ve Otelcilik Yüksekokulu, İstiklal Yerleşkesi, 15030, Burdur. \\ E-posta: yesiltas.murat@gmail.com
}

\author{
MAKALE BILGILERI \\ Makale işlem bilgileri: \\ Gönderilme tarihi: 30 Temmuz 2013 \\ Birinci değerlendirme: 26 Eylül 2013 \\ İkinci değerlendirme: 1 Ekim 2013 \\ Üçüncü değerlendirme: 7 Ekim 2013 \\ Kabul: 7 Ekim 2013 \\ Anahtar sözcükler: \\ Etik iklim, İşe yabanculaşma, Işsten \\ ayrulma niyeti, Otel işletmeleri, \\ Örgütsel özdeşleşme.
}

\begin{abstract}
ÖZ
Etik iklim, işlerin örgüt içinde etik temelli olarak nasıl yürütüldüğünü ifade eden bir kavram olarak değerlendirilmektedir. Örgütlerde etik iklim, bireyin benliği ve sahip olduğu değerler ile uyumlu olmaması durumunda, birçok psikolojik temelli sonuca yol açabilmektedir. Bu çalışmada; etik iklim, işe yabancılaşma ve örgütsel özdeşleşmenin işten ayrılma niyeti üzerindeki etkisi araştırılmıştır. Araştırma, Ankara ve Antalya illerindeki beş yıldızlı otel ișletmelerinde çalışan 385 işgörenle yürütülmüștür. Çalıșmada, değișkenler arasındaki etkileri ölçmek amacıyla yapısal eşitlik modelinden yararlanılmıştır. Araştırma sonucunda, etik iklim türleri olan kişisel ahlak ve kişisel çıkarın yabancılaşma üzerinde, kişisel çıkarın örgütsel özdeșleşme üzerinde, özdeşleşmenin ve yabancılaşmanın işten ayrılma niyeti üzerinde etkisi olduğu tespit edilmiştir. Bununla birlikte, diğer etik iklim türlerinin özdeşleşme ve yabancılaşma üzerinde etkisinin olmadığı sonucuna ulaşıımıştır.
\end{abstract}

\author{
ARTICLE INFO \\ Article history: \\ Submitted: 30 July 2013 \\ Resubmitted: 26 September 2013 \\ Resubmitted: 1 October 2013 \\ Accepted: 7 October 2013 \\ Key words: \\ Ethical climate, Hotel enterprises, \\ Organizational identification, \\ Turnover intentions, Work alienation.
}

\begin{abstract}
The effect of ethical climate, work alienation and organizational identification on the turnover intentions of the employees is investigated in this study. Ethical climate, which is a concept that expresses how the business in the organization is done ethically, can lead to many psychological outcomes if it does not match with the individual's self-concept and his values. The effects of ethical climate on work alienation, organizational identification and turnover intentions of the employees have been investigated in this study. The research has been conducted with 385 hotel employees who work for five star hotel enterprises in Ankara and Antalya regions. In order to measure the effects between the variables, structural equation modeling has been used in the study. The effect of personal morality and self-interest, as two types of ethical climate, on alienation, effect of self-interest on organizational identification and the effect of identification and alienation on the turnover intentions of the employees have been identified in this study. However, any effects of other ethical climate types on identification and alienation have not been determined.
\end{abstract}

\section{Giriş}

Etik iklim (Eİ), örgüt içindeki ilişkileri ve işgörenlerin davranışlarını ve dolayısıyla örgütsel sonuçları etkileyen önemli faktörlerden biridir. Örgüt içinde yer alan yaygin etik iklim türü bireyin neyin doğru veya yanlış olduğuna karar vermesinde ve davranış şekillerinde etkilidir (Bulutlar ve Öz 2009: 273). İşletmelerde yer alan yaygın etik iklim türleri işgörenlerin davranışları ve hareketleri üzerinde belirleyicidir ve bu iki değişken arasındaki ilişki incelenen konular arasındadır (Elçi ve Alpkan 2009: 297). Daha önceki çalışmalar, etik iklimin bireyin davranış ve niyetleri üzerinde etkili olduğunu göstermektedir (Smith, Thompson ve Iacovou 2009: 577). Etik iklim, son on yıldır yoğun olarak bireyin davranışları üzerindeki etkileri bakımından ele alınmaktadır (DeConnick 2010: 384). Etik iklime yönelik yapılan araştırmalar sadece etikle ilgili de- 
ğişkenleri içermemekte, aynı zamanda bu çalışmalar örgütsel sonuçları da kapsamaktadır (Martin ve Cullen 2006). Örneğin, işyerindeki etik iklim işgörenlerin; iş tatmini (Elçi ve Alpkan 2009), örgütsel bağlllığ 1 (Cullen, Parboteeah ve Victor 2003; Öğüt ve Kaplan 2011), örgütüyle özdeşleşmesi (DeConnick 2011) üzerinde, işyerinde zorba davranışların oluşmasında (Bulutlar ve Öz 2009) ve örgütte amaca zarar veren davranışlar sergilemesinde (Vardi 2001) etkilidir.

Örgütlerdeki etik iklim, birçok psikolojik temelli davranışın açıklayıcısı konumundadır. Buradan hareketle etik iklimin örgütsel özdeşleşme ve işe yabancılaşma üzerinde de etkili olduğunu söylemek mümkündür. Örgütsel özdeşleşme iş ilişkilerinde kritik öneme sahiptir. Örgütsel özdeşleşmeyi neyin güçlendirdiğinin anlaşılması, hem örgütsel hem de bireysel düzeyde sonuçların anlaşılması bakımından önemlidir (Tüzün ve Çağlar 2009: 284). DeConinck'in (2011: 621) satış görevlilerine yönelik gerçekleştirmiş olduğu çalışmada, yönetim kademelerinde bulunanların örgüt içinde sorumluluk/güven artırılması, etik normların desteklenmesi ve etik satış unsurlarının artırılmasıyla çalışanlar tarafından bu değerlerin içselleştirileceği belirtilmektedir. Bu nedenle etik iklimin örgütsel özdeşleşme üzerinde önemli derecede etkili olduğu söylenebilir.

Birey örgütüyle psikolojik bir bütünleşme sağladığında iş tatmini artmakta, devamsızlık ve işten ayrılma gibi işle ilgili sonuçları olan davranışları sergilememektedir. Aynı zamanda böyle bir durum bireyin daha yüksek performans sergilemesine ve yaptığ 1 işte motivasyonunun artmasına neden olmaktadır (VanKnippenberg ve Sleebos 2006: 571). Bu durum işe yabancılaşma açısından da aynen geçerlidir.

Etik iklim türleri ve etkileri ile ilgili (örgütsel bağlılık, sapma davranışları ve iş tatmini vb.) alan yazında birçok çalışma olmasına rağmen, örgütsel özdeşleşme ve işten ayrılma niyeti üzerindeki etkisini araştıran sınırlı sayıda çalışma bulunmaktadır. Bununla birlikte alan yazında etik iklimin işe yabancılaşma üzerinde etkisini araştıran çalışmaya ise rastlanılamamıştır. Çalışmanın amacı etik iklimin örgütsel özdeşleşme, işe yabancılaşma ve işten ayrılma niyeti üzerindeki etkilerini araştırmaktır. Bu amaç doğrultusunda, çalışmada ikincil verilerle oluşturulan araştırma modeli yapısal eşitlik modeli ile test edilmiştir.

\section{KAVRAMSAL ÇERÇEVE}

\section{Etik İş İklimi}

Kavramsal açıdan etik iklim, örgütsel iş ikliminin bir türüdür. Etik iş iklimi, örgütsel davranış çalışmalarıyla birlikte sosyoloji ve uygulamalı psikolojide oldukça fazla yer almaktadır (Martin ve Cullen 2006: 176). İş iklimi, işgörenlerin "burada işler ne şekilde yapılmaktadır" algılamasını oluşturmaktadır. Kavram, işgörenin örgüt tarafından ödüllendirilen, desteklenen ve beklenilen davranışlara yönelik örgütün politikalarını, prosedürlerini ve uygulamalarını algılaması olarak ifade edilebilir (Schminke, Arnaud ve Kuenzi 2007: 175). Örgüt içerisinde birçok iş iklimi bulunsa da örgütün etik iklimi bireylerin etik davranışlarını şekillendirmesi nedeniyle önemlidir (DeConnick 2011: 618).

Örgütlerin sahip olduğu etik iklim türleri; hangi konuların etik olarak sürdürülmesine ve bununla ilgili hangi konuların anlaşılması, neye ağırlık verilmesi ve çözüm önerilerinin ne şekilde olması gerektiği gibi farklı konularda karar verilmesine yardımcı olmaktadır (Cullen, Victor ve Stephens 1989: 51).

Etik iş iklimi, ilk olarak Victor ve Cullen (1987) tarafından ortaya konulmuştur (VanSandt, Shepard ve Zappe 2006: 410). Araştırmacılar daha sonra etik iklimi; "etik çerçevede doğru davranışın ne olduğuna yönelik ortak algılamalar ve etik konuların değerlendirme biçimi" şeklinde tanımlamışlardır (Victor ve Cullen 1988: 104). Bu tanımlamaya göre etik iklim, bütün örgütlerde hatta örgütün kendi içerisinde bile farklılık göstermektedir (Rothwell ve Baldwin 2006: 219).

Etik iklim bir iş iklimi türü olarak ahlaki sonuçlara sahip örgütsel politikaları, prosedürleri, uygulamaları yansitmaktadır (Mulki, Jaramillo ve Locander 2008: 560-561). Güçlü bir etik iklim, örgüt içerisinde biçimsel olmayan bir kontrol sağlamakta; aynı zamanda bireylerin nasıl davranması gerektiğini ve sorumluluklarını anlamasına, çalışanların doğru ve yanlışlarını görmesine olanak sağlamaktadır (Lopez, Babin ve Chung 2009: 595).

Teorik olarak etik iklim, çalışanlar tarafından kullanılan analiz düzeyi ve etik düşünmeye yarayan kriterlerin veya kuralların bir fonksiyondur. Örgütlerdeki etik kriterler, bireyin bilişsel ahlaki gelişim düzeyine dayanmaktadır ve etik karar vermede belirleyicidir (Lemmergaard ve Lauridsen 2008: 654). Bu temelde Victor ve Cullen (1987, 
1988) dokuz bileşenli bir etik iklim matrisi oluşturmuştur. Bu matriste; egoizm (kendi çıkarını en üst düzeye çıkarma), yararcılık (olabildiğince fazla sayıda insanın çıkarını en üst düzeye çıkarma) ve ilkelilik (evrensel standart ve değerlere taraftar olma) olmak üzere üç etik kriter ile bireysel, yerel (örgüt) ve evrensel (örgüt dışı) temelde farklı analiz düzeyleri yer almaktadır (Appelbaum, Deguire ve Lay 2005: 44). Schminke, Ambrose ve Neubaum (2005:137) analiz düzeyinin oluşturulmasında sosyal rol teorisinin (Goeldner 1957) takip edildiğini ifade etmektedir. Teoride yer alan bireysel düzey, grup düzeyi ve toplumsal düzeyin bireysel, yerel ve evrensel olarak matriste yer aldığ́1 görülmektedir. Buna ilaveten Victor ve Cullen $(1987,1988)$ etik kriterler olarak belirlenen egoizm, yararcılık ve ilkelilik kriterlerini de Kohlberg'in (1967) bilişsel ahlaki gelişim düzeyine dayandırmaktadırlar (Parboteeah vd. 2010: 600). Bununla birlikte Victor ve Cullen'in (1988) yapmış olduğu düzenleme, Kohlberg'in düzenlemesinin örgütsel düzeye uyarlanması nedeniyle orijinal sınıflandırmadan farkl1lik göstermektedir (Ambrose, Arnaud ve Schminke 2008: 325).

Peterson (2002), Victor ve Cullen'ın (1988) çalışmasında yer alan teorik etik iklim türlerinin tamamının örgütlerde görülmesinin beklenilmemesi gerektiğini ve hatta ankette kullanılan soruların dahi farklı iklim türleri altında çıkabileceğini ifade etmektedir. Alanyazın incelendiğinde yardımseverlik, bağımsızlık, yasalar ve kodlar, araçsallık ve kurallar etik iklim türlerinin alanyazında yoğun olarak öne çıktığı, bununla birlikte Wimbush, Shepard ve Markham'ın (1997) çalışmalarında yer alan hizmet, yasa ve kurallar isimli iklim türü ve Barnett ve Vaicys'nin (2000) çalışmalarında belirlenen takım/arkadaşlık ve sosyal sorumluluk etik iklim türlerine benzer etik iklim türlerinin çalışmalarda yer aldığı görülmektedir.

\section{Örgütsel Özdeşleşme}

Alanyazın incelendiğinde örgütsel özdeşleşmenin Sosyal Kimlik Teorisi (SKT) (Tajfel 1982; Tajfel ve Turner 1983) temelli bir kavram olduğu görülmektedir (Akt. Epitropaki ve Martin 2005: 570; DeConnick 2011: 618). SKT'ye göre özdeşleşme; kişilerin sosyal bağlılığını oluşturan bir süreçtir (Epitropaki ve Martin, 2005: 570). Bu süreç içerisinde bireyin ve örgütün amaçları bütünlük oluşturmakta veya aynı noktada buluşmaktadır (Hall, Schneider ve Nygren, 1970: 176-177).

Bireyin sahip olduğu benlikle algıladı̆̆ kimliğin aynı olduğunu düşünmesi, örgütsel özdeşleşme olarak bilişsel bağlılığı oluşturmaktadır. Örgütsel özdeşleşme bireyin sahip olduğu değerlerle, örgütte algıladıklarının derecesi olarak tanımlanabilir (Dutton, Dukerich ve Harquail 1994: 239). Bu durum göz önüne alınarak örgütsel özdeşleşme için bireyin benliği ile örgüt arasında oluşan psikolojik bir birleşme olduğunu söylemek yanlış olmaz (Van Kippenberg ve Sleebos 2006: 572). Mael ve Ashforth (1992: 104) ise örgütsel özdeşleşmeyi “ bireyin mensubu olduğu örgütle ilgili olarak kendini tanımlaması, örgüte yönelik aidiyet veya bütünlük algılaması" olarak tanımlamıştır. Bu tanımlamalar göz önüne alındığında örgütsel özdeşleşmenin bilişsel bir yapı olduğu ortaya çıkmaktadır (Riketta 2005: 360).

Bireyin etik anlayışıyla örgütün etik kültürü arasindaki farklılıklar nedeniyle zaman zaman etik uyumsuzluklar yaşanabilmektedir. Örgütün ve bireyin sahip olduğu etik ilkelerin uzlaşamaması, örgüt içerisinde bir çatışmaya neden olabilir. Örgüt ve birey arasındaki çatışmalar etik değerlerin farklı standartlarla, farklı bakış açılarından oluşmasından meydana gelmektedir.

Kişi ve örgüt uyumu, kişinin ve örgütün birbirlerini tercihlerinde etkilidir. Genellikle böyle bir durum karşılıklı uyuma bağlıdır. Bahsi geçen uyum ise birey ve örgütün inançlarının, değerlerinin birbiriyle uyumudur (Valentine, Godkin ve Lucero 2002: 350). Birey ve örgüt arasındaki değer uyumunun yüksek olması, her iki taraf açısından da olumlu sonuçlar doğurmaktadır. Bu uyum, çalışanların özellikle işe yönelik tutum ve davranışlarında olumlu sonuçlar meydana getirmektedir (Kılıç 2010: 21). Böyle bir durum derecelendirilecek olursa, yüksek düzeyde uyum bireyin örgüte yönelik özdeşleşme düzeyine olumlu olarak yansır. Tersi bir durum ise örgütle özdeşleşmemeye neden olacaktır (Valentine vd. 2002: 350).

Etik iş iklimi algılaması, birey örgüt uyumuyla bütünleştiği takdirde, kendini örgütle daha fazla uyumlu hissetmesine neden olmaktadır. Örgütün ya da bireyin etik anlayışa sahip olması, bireyin işe yönelik özdeşleşmesi üzerinde de etkilidir. Eğer işgören üst düzeyde etik anlayışa sahipse ve aynı etik anlayışı örgütte bulamıyorsa; bireyin başarısı 
adına değerlerin uyumu konusunda bir baskı söz konusudur. Eğer tersi bir durum söz konusuysa, yani örgüt etik değerler konusunda sert bir tavır sergiliyorsa, böyle bir baskı altında da birey kendini rahat ifade edemeyebilir. Bireyin örgüte yönelik düşüncelerinde farklılıklar ortaya çıkabilir (Lopez vd. 2009: 595).

\section{İşe Yabancılaşma}

Kişinin işinden, çevresinden ya da benliğinden ayrilma veya uzaklaşma duygusunu dile getiren yabancılaşma; daha çok kişinin bireysel temelde kurumlardan, kendisinden, değerlerinden, toplumsal oluşum ve organizasyonlardan uzaklaşması olarak değerlendirilebilir (Şimşek vd. 2006: 573). Yabanc1laşma, yalnızca siyasal ve ekonomik temelli ilişkilerde bozulma olmayıp, bütün ilişkilerde bir bozulmayı ifade etmektedir. Bu bozulmanin sonucunda, kişiler kendi özüne ve benliğine uygun olmayan biçimde yaşamak zorunda kalabilirler.

Bireyin örgütten psikolojik olarak, fiziksel olarak veya her iki şekilde birden uzaklaşması yabancılaşmanın varlığını göstergesidir. Bireyin işe yabancılaşması ile işyerindeki çalışma koşullarının yakından ilişkisi vardır (DiPietro ve Pizam 2008). Bu ilişki, yabancılaşmanın kişisel bir özellik olmasından ziyade "durumsal olarak gelişen" bir kavram olduğunu göstermektedir. Dolayısıyla işyerindeki şartların yabancılaşmanın gelişmesinde etken olduğunu belirtmek yerinde olacaktır (Banai, Reisel ve Probst 2004: 377). Örgütün sahip olduğu kültürel ve ahlaki özellikler ile bireyin sahip olduğu değerler, idealler ve arzuların birbiriyle uyumlu olmaması da bireyde yabancılaşmaya neden olabilmektedir (Sulu, Ceylan ve Kaynak 2010).

Yabancılaşma, genellikle bürokratik yapı ve merkezi karar alma, biçimsel kurallar ve politikaların egemen olduğu işyerlerinde görülmektedir. Örgüt içinde merkezileşme ve biçimselleşme, yabancilaşmaya öncülük eden iki yapısal şartı ifade etmektedir (Sarros vd. 2002). Banai ve arkadaşları (2004) ise işyerindeki genel şartların aynı zamanda işe yabancilaşmaya da etki ettiğini ifade etmektedir.

Yabancılaşma kavramı akademik çalışmalarda ilk olarak güçsüzlük veya iş üzerinde kontrol kaybı şeklinde tek yapılı bir bileşen olarak ele alınmıştır (Nair ve Vohra 2009). Seeman $(1959,1967)$ ise yabancılaşmayı; güçsüzlük, anlamsızlık, normsuzluk (kuralsızlık), toplumsal anlamda izolasyon ve ben- lik yabancılaşması olarak beş farklı boyutta sınıflandırmıştır.

\section{İşten Ayrılma Niyeti}

İşten ayrılma niyeti, örgütler üzerinde doğrudan ve dolaylı maliyetleri olması nedeniyle oldukça önemli bir konudur. Örgütlerin toplam maliyetleri içinde işten ayrılmaların \%15-30 oranında bir paya sahip olduğu dikkate alındığında, konunun önemi daha iyi anlaşılacaktır (Jang ve George 2012: 590). Doğrudan ve dolaylı maliyet oluşturması, yönetsel ve örgütsel problemlerinin yanında özellikle turizm ve otelcilik gibi hizmet odaklı sektörlerde mal ve hizmet kalitesinde ve müşteri memnuniyetsizliği üzerinde işten ayrılma niyetinin olumsuz etkileri olduğu görülmektedir (Sims 2007; Kim 2012).

İşten ayrılma niyeti, bireyin işini bırakmasına yönelik bir uyarı işareti olduğu gibi bireylerin iş değiştirme eğilimlerini tespit etmede oldukça etkili bir öncüldür (Jung, Nankung ve Yoon 2010: 539). Cotton ve Tuttle (1986) işten ayrilma niyetine etki eden faktörleri üç başlık altında toplamıştır. Bu faktörler; dışsal faktörler (işgörenlerin algıları, işsizlik oranları ve tekrar işe başlama oranı vb.), kişisel faktörler (yaş, cinsiyet, çalışma yıllı, eğitim, medeni hal vb.) ve işle ilgili faktörlerdir (ücret, iş performansı, yapılan işin tanımı, iş tatmini, verilen görevin rutin olması, yükselme olanaklar vb.). Buna ilaveten alan yazında işle ilgili faktörlerin işten ayrılma niyeti üzerindeki etkilerine farklı değişkenlerin de etki ettiğine ilişkin çalışmalar yer almaktadır.

Ünsar ve Karahan (2011), bireylerin işlerine yabancılaşmalarının, zamanla işten ayrılmalara neden olduğunu belirlemiştir. Sulu ve arkadaşları (2010) ise yabancılaşmanın bireylerin motivasyonunu azalttığını, bu durumda bireyin psikolojik olarak işten ayrıldığını veya kişinin işe bağlılığının zayıfladığını vurgulamıştır.

Örgütsel özdeşleşme, sonuçları açısından alan yazında yoğun olarak incelenen bir kavramdır (Elsbach ve Bhattacharya 2001; Riketta 2005; Mignonac, Herrbach ve Guerrero 2006). Özdeşleşmeye yönelik yapılan araştırmalarda, bu kavramın sonuçlarının; iş tatmini, iş performansı, işgören devir hızı gibi bazı örgütsel davranışlar üzerinde etkili olduğu görülmektedir (VanKnippenberg 2000; VanDick ve Wagner 2002; Haslam, Eggins ve Reynolds 2003; Katrinli vd. 2009). Yapılan bu çalışmalarda, örgütsel özdeşleşmenin işten ayrılma niye- 
tini azalttığ1 tespit edilmiştir (Wan-Huggins, Riordan ve Griffeth 1998: 732; VanDick vd. 2004: 354; Öz ve Bulutlar 2009: 39). Örgütsel özdeşleşmede bireyin benlik kavramıyla örgüt örtüşmekte; normlar ve değerler, örgütsel amaçlarla birey amaçları uyumlaşmaktadır (VanDick vd. 2004: 353). Bu durum bireyi işte kalmaya yöneltmekte; aksi durumda ise işten ayrılmalar görülmektedir.

İşgören devir hızı örgütsel özdeşleşme düzeyi açısından değerlendirildiğinde; özdeşleşmenin sonucu ile en yakın ilişki içinde olan ve genellikle örgütler tarafından arzulanmayan bir kavram olduğu görülmektedir. İşgören devir hızı örgütler üzerinde birçok olumsuz sonuçlar doğurabilmektedir. $\mathrm{Bu}$ olumsuz sonuçlar arasında; işgörenin yeniden teminin yol açtığ 1 maliyetler, eğitim maliyetlerinin artması, çalışanların moral düzeyinin düşmesi, iş tatminsizliği ve hizmet kalitesinin düşmesi yer almaktadir (Tuna 2007; Cho, Johanson ve Guchait 2009: 374).

\section{YÖNTEM}

Çalışmada ikincil verilerle birlikte, birincil veriler de kullanılmıştır. Birincil verilere yönelik veri toplama tekniği olarak anket yönteminden yararlanılmıştır. Anket formunun hazırlanmasında, daha önce geçerlilik ve güvenilirliği test edilmiş ölçekler kullanılmıştır.

\section{Araştırmanın Modeli ve Hipotezler}

Bu çalışmada örgütlerde bulunan etik iklim türlerinin; bireylerin yabancılaşma, özdeşleşme ve işten ayrılma niyetlerine etkisi incelenmektedir. Zira örgüt içindeki etik iklim, bireylerin işteki özerkliğini kaybetmesine, güçsüzleşmesine ve örgüt içindeki normları kabul etmemesine neden olabilmektedir. Bununla birlikte, örgüt içindeki değerlerle bireyin değerlerinin uyumsuz olması da bireyin özdeşleşmesi üzerinde olumsuz yönde etkilidir. Bu düşünceden hareketle çalışmada; etik iklim türlerinin yabancılaşma ve özdeşleşme üzerindeki etkileri incelenmiş, aynı zamanda yabancılaşmanın ve özdeşleşmenin işten ayrılma niyeti üzerindeki etkileri de araştırılmıştır. Araştırma hipotezleri aşağıdaki gibidir:

$\mathrm{H}_{1 \mathrm{a}}$ : Otel işletmelerinde yardımseverlik etik iklimi bireyin işe yabancılaşmasına negatif etki etmektedir.

$\mathrm{H}_{1 \mathrm{~b}}$ : Otel işletmelerinde yasalar ve kodlar etik ik- limi bireyin işe yabancılaşmasına negatif etki etmektedir.

$\mathrm{H}_{1 \mathrm{c}}$ : Otel işletmelerinde kişisel ahlak etik iklimi bireyin işe yabancılaşmasına negatif etki etmektedir.

$\mathrm{H}_{1 \mathrm{~d}}$ : Otel işletmelerinde kurallar etik iklimi bireyin işe yabancılaşmasına negatif etki etmektedir.

$\mathrm{H}_{1 \mathrm{e}}$ : Otel işletmelerinde örgüt yararı etik iklimi bireyin işe yabancılaşmasına negatif etki etmektedir.

$\mathrm{H}_{1 \mathrm{f}}$ : Otel işletmelerinde verimlilik etik iklimi bireyin işe yabancılaşmasına pozitif etki etmektedir.

$\mathrm{H}_{1 \mathrm{~g}}$ : Otel işletmelerinde kişisel çıkar etik iklimi bireyin işe yabancılaşmasına pozitif etki etmektedir.

$\mathrm{H}_{2 \mathrm{a}}$ : Otel işletmelerinde yardımseverlik etik iklimi örgütsel özdeşleşmeye olumlu etki etmektedir.

$\mathrm{H}_{2 \mathrm{~b}}$ : Otel işletmelerinde yasalar ve kodlar etik iklimi örgütsel özdeşleşmeye olumlu etki etmektedir.

$\mathrm{H}_{2 c}$ : Otel işletmelerinde kişisel ahlak etik iklimi örgütsel özdeşleşmeye olumlu etki etmektedir.

$\mathrm{H}_{2 \mathrm{~d}}$ : Otel işletmelerinde kurallar etik iklimi örgütsel özdeşleşmeye olumlu etki etmektedir.

$\mathrm{H}_{2 \mathrm{e}}$ : Otel işletmelerinde örgüt yararı etik iklimi örgütsel özdeşleşmeye olumlu etki etmektedir.

$\mathrm{H}_{2 \mathrm{f}}$ : Otel işletmelerinde verimlilik etik iklimi örgütsel özdeşleşmeye olumlu etki etmektedir.

$\mathrm{H}_{2 \mathrm{~g}}$ : Otel işletmelerinde kişisel çıkar etik iklimi örgütsel özdeşleşmeye negatif etki etmektedir.

$\mathrm{H}_{3}$ : Otel işletmelerinde işe yabancılaşma işten ayrılma niyeti üzerinde pozitif yönlü bir etkiye sahiptir.

$\mathrm{H}_{4}$ : Otel işletmelerinde örgütsel özdeşleşme işten ayrılma niyeti üzerinde negatif yönlü bir etkiye sahiptir.

\section{Araştırmada Kullanılan Ölçekler}

Etik İklim Anketi: Araştırmada etik iklimi ölçmek amacıyla Victor ve Cullen (1988) tarafından oluşturulan 26 maddelik etik iklim ölçeğinden yararlanılmıştır. Ölçeğin Türkçe geçerlilik ve güvenilirlik çalışması birçok çalışmada mevcuttur. Bu çalışmada ise Kaplan'ın (2010) çalışmasında yer alan ve otel işletmelerinde daha önce kullanılan ölçekten faydalanılmıştır.

İşe Yabancılaşma: Ölçek, Hirschfeld ve Feild

Cilt $25 \bullet$ Sayı $1 \bullet$ Bahar $2014 \bullet 109$ 


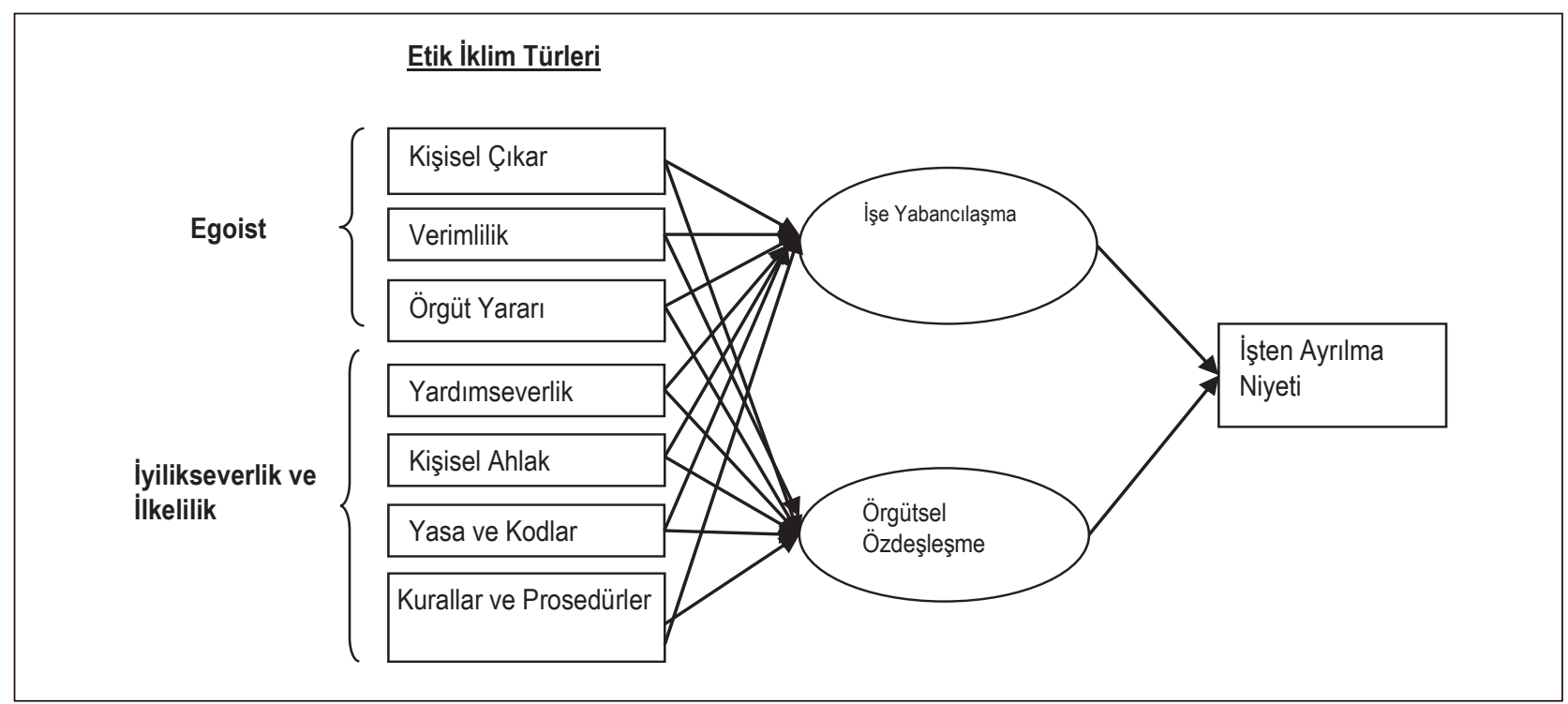

Şekil 1. Araşttrma Modeli

(2000) tarafından geliştirilmiş olup toplamda 10 maddeden oluşmaktadır. Yazarlar, Maddi, Kobasa ve Hoover (1979) tarafından geliştirilen 12 maddelik ölçme aracında düzenleme yapmış ve beş maddeyi değiştirmişlerdir. Ölçeğin Türkçe geçerlilik ve güvenilirlik çalışması Özbek (2011) tarafından yapılmıştır. Bununla birlikte çalışmada Özbek tarafından oluşturulan Türkçe ölçek üzerinde bazı düzeltmeler yapılmıştır.

Örgütsel Özdeşleşme Ölçeği: Örgütsel özdeşleşmeyi ölçmek amaciyla Mael ve Ashforth (1992) tarafından oluşturulan altı maddelik tek faktörlü ölçekten faydalanılmıştır. Bu ölçeğin Türkçe geçerlilik ve güvenilirlik çalışması Tüzün (2006) tarafından yapilmıştır.

İşten Ayrılma Niyeti Ölçeği: Bu ölçek, Wayne, Share ve Lindon (1997) tarafından altı madde olarak hazırlanmıştır. Küçükusta (2007) altı maddelik ölçeğin geçerlilik ve güvenilirlik çalışmasını yapmış ve üç maddenin güvenilirliği bozduğunu tespit etmiştir. Bu çalışmada da söz konusu üç madde ölçekten çıarılmış ve Türkçe geçerlilik ve güvenirliği sağlanmış biçimde kullanılmıştır.

\section{Evren ve Örneklem}

Araştırmanın evrenini, Ankara ve Antalya'da bulunan beş yıldızlı otel işletmeleri çalışanları oluşturmaktadır. Bu illerin araştırmanın evreni olarak belirlenmesinin nedeni; Ankara' nın şehir otelciliğinde, Antalya'nın ise sayfiye turizminde önemli örnekler arasında yer almasıdır. Bu iller içerinde yer alan sekiz adet beş yıldızlı otel işletmesinde çalışanlarla kolayda örneklem alma yöntemi ile görüşülmüştür. Araştırmada asgari örneklem sayısı, $\% 95$ güvenilirlik sınırları içerisinde ve $\% 5^{\prime}$ lik bir hata payı dikkate alınmak koşuluyla 384 'tür (Altunışık vd. 2005: 127).

\section{BULGULAR}

\section{Tanımlayıcı Bulgular}

Araştırmaya katılanların \%55,2'si erkeklerden, $\% 44,7^{\prime}$ si ise bayan çalışanlardan oluşmaktadır. Çalışanların yarıdan fazlası 20-29 yaş aralığında (\%51,9) olup, bunu 30-39 yaş aralığında $(\% 21,8)$ çalışanlar takip etmektedir. Araştırmaya katılanların $\% 47,8$ 'inin ortaokul mezunu, $\% 21,3$ 'ünün üniversite mezunu ve $\% 18,2$ 'sinin ise meslek yüksekokulu mezunu olduğu görülmektedir. Buna ilaveten katılımcıların çok küçük bir kısmının lisansüstü eğitim derecesine sahip olduğu tespit edilmiştir. Örneklem içerisinde yer alan grubun turizm sektöründe çalışma süresi incelendiğinde; cevap verenlerin $\% 34,8^{\prime}$ inin 1-3 yıldır, \%25,2'sinin ise 4-6 yıldır turizm sektöründe çalışmakta olduğu belirlenmiştir. 10 yıl ve daha fazla deneyime sahip olanların oranı \%9,9'dur. İşletmelerin sahiplik yapısına bakıldığında \%61,6'sının bağımsız, \%19,2'sinin uluslararası otel zinciri, \%18,7'sinin ise ulusal zincir otel işletmelerinden oluştuğu görülmektedir. 


\section{Faktör Analizine İlişkin Bulgular}

Alanyazında yer alan birçok çalışmanın aksine bu çalışmada, varimaks döndürme tekniği ile yap1lan açıklayıcı faktör analizi sonucunda yedi farklı etik iklim türü (yasa ve kodlar, kişisel ahlak, kurallar, örgüt yararı, verimlilik, kişisel çıkar ve yardımseverlik) oluşmuş̧tur. Analiz sonucunda ortaya çıkan söz konusu yedi faktör, toplam varyansın $\% 61,105$ 'ini açıklamaktadır. Tablo 1 incelendiğinde her bir faktörün güvenilirliği a $>, 60$ olarak bulunmuş ve bu değerler kabul edilebilir sınırın üzerinde olduğu için faktör güvenilirliği sağlanmıştır (Kalaycr 2005: 404-405).
Yapılan açıklayıcı faktör analizi neticesinde, ölçeğin yasa ve kodlar, kişisel ahlak, kurallar, örgüt yararı, verimlilik, kişisel çıkar ve yardımseverlik iklim türleri alt boyutlar olarak ortaya çıkmıştır (Tablo 1). Söz konusu boyutlar arasında yer alan altı iklim türü, oluşturulan etik iklim tipolojinde yer alan iklim türleridir. Yardımseverlik iklim türü ise iyilikseverlik etik kriterinde yerel ve bireysel analiz düzeyinde ortaya çıkan ve alan yazında yoğun karşılaşılan iklim türüdür. Bir başka ifadeyle yardımseverlik iklim türü alan yazında deneysel olarak kanıtlanmış bir iklim türüdür.

Tablo 1. Etik İklim Ölçeğine Yönelik Faktör Analizi Sonuçları

\begin{tabular}{|c|c|c|c|c|c|c|c|}
\hline Ifadeler & Yardımseverlik & Yasa ve Kodlar & Kişisel Ahlak & Kurallar & Şirket Yararı & Verimlilik & Kişisel Çıkar \\
\hline EIÖ2 & ,844 & & & & & & \\
\hline EIÖ1 & ,818 & & & & & & \\
\hline Eï̈3 & ,796 & & & & & & \\
\hline ElÖ4 & ,618 & & & & & & \\
\hline ElÖ15 & & ,705 & & & & & \\
\hline Eiö9 & & ,703 & & & & & \\
\hline ElÖ10 & & 659 & & & & & \\
\hline Eiö11 & &, 517 & & & & & \\
\hline Eiö8 & & ,486 & & & & & \\
\hline ElÖ26 & & & ,827 & & & & \\
\hline ElÖ25 & & &, 794 & & & & \\
\hline ElÖ24 & & & ,771 & & & & \\
\hline ElÖ23 & & & ,612 & & & & \\
\hline Eï̈13 & & & & ,837 & & & \\
\hline EiÖ12 & & & & ,757 & & & \\
\hline ElÖ14 & & & &, 592 & & & \\
\hline ElÖ19 & & & & & ,706 & & \\
\hline ElÖ20 & & & & & ,668 & & \\
\hline ElÖ21 & & & & & ,630 & & \\
\hline ElÖ22 & & & & & ,624 & & \\
\hline ElÖ5 & & & & & & ,722 & \\
\hline Eiö7 & & & & & & ,630 & \\
\hline EIÖ6 & & & & & &, 569 & \\
\hline ElÖ17 & & & & & & & $\overline{8,821}$ \\
\hline Eiö16 & & & & & & & ,801 \\
\hline Eiö18 & & & & & & &, 522 \\
\hline Faktör güvenilirlikleri & eri $\quad \alpha=0,793$ & $\alpha=0,779$ & $\alpha=0,776$ & $\alpha=0,744$ & $\alpha=0,651$ & $\alpha=0,669$ & $\alpha=0,632$ \\
\hline Ölçek Güvenilirliği & & & & 0,823 & & & \\
\hline Varyans \% & 10,189 & 9,641 & 9,466 & 8,738 & 8,060 & 7,575 & 7,436 \\
\hline Özdeğer & 5,600 & 2,821 & 2,125 & 1,691 & 1,590 & 1,039 & 1,022 \\
\hline
\end{tabular}

KMO: 0,805; Ki-kare değeri: 328,103; Sig.değeri: ,000; df: 325; Varyans açıklama oranı: \% 61,105 
Tablo 2. Araştırmada Kullanılan Diğer Ölçeklere Yönelik Faktör Analizi Sonuçları

\begin{tabular}{lll}
\hline Iş̧e Yabancılaşma Ölçeği & Ifadeler & \\
\hline & IYAB4 &, 813 \\
IYAB8 &, 779 \\
IYAB5 &, 761 \\
IYAB6 &, 746 \\
IYAB7 &, 742 \\
IYAB2 &, 739 \\
IYAB3 &, 728 \\
IYAB9 &, 719 \\
IYAB10 &, 603 \\
IYAB1 &, 600
\end{tabular}

KMO: 0,918; Ki-kare değeri: 177,703; Sig. değeri: .000; df: 45; Varyans açıklama oranı: \%52,712 a=0,899

Örgütsel Özdeşleşme Ölçeği $\quad$ ÖÖ4 , 815

ÖÖ3

ÖÖ5

ÖÖ6 $\quad$,776

ÖÖ2

ÖÖ1

KMO: 0,864; Ki-kare değer: 994,703; Sig. değeri: .000; df: 15; Varyans açıklama oranı: \% 59,997; a= 0,866

IAN

IAN1*

IAN2*

,899

IAN3*

,830

KMO: 0, 702: Ki-kare değer: 559,573; Sig. değeri: ,000; df: 3;Varyans açıklama oranı: $\% 77,742 ; \quad a=0,852$

* $=$ Ters Kodlama

Araştırmada kullanılan diğer ölçeklere yönelik açıklayıcı faktör analizi yapılmış (Tablo 2) ve her bir ölçekte tek faktörlü yapı ortaya çıkmıştır. Ölçekler için yapılan faktör analizinde, faktör yükü 0,4'ün altında olan (Şencan 2005: 390) herhangi bir ifadenin olmadığı görülmüştür. İşe yabancılaşma ölçeği toplam varyansın \%52,712'sini açılamaktadır. Ölçeğin KMO değeri 0,918 ve Bartlett testi soncu ise $X^{2}(45)=177,703$ 'dir. Örgütsel özdeşleşme ölçeği toplam varyansın \%59,997'sini açıklamaktadır. Ölçeğin KMO değeri 0,864, Bartlett testi sonucu ise $X^{2}(15)=994,703$ olarak belirlenmiştir. Araştırmada kullanılan işten ayrılma niyeti ölçeği toplam varyansın \%77,742'sini açıklamaktadır. Ölçeğin KMO değeri 0,702 olarak tespit edilmiştir.

Bartlett testi $X^{2}(3)=559,573$ olarak gerçekleşmiştir. KMO değerinin 0,5-0,10 arasında olması kabul edilebilir değerleri ifade etmektedir. Bir başka ifadeyle, bu değer aralığ faktör analizine uygunluğu gösteren bir indistir. Bununla birlikte araştırmacılara tatminkâr gelen indis 0,7'dir (Altunışık vd 2005). Araştırmada kullanılan ölçeklerin güvenilirlikleri $\alpha=0,899, \alpha=0,866$ ve $\alpha=0,852$ olarak belirlenmiştir. Çalışmada yer alan ölçeklerin yeterli güvenilirliğe sahip olduğu söylenebilir.

\section{Korelasyon Analizine İlişkin Bulgular}

Tablo 3'te araştırmaya konu olan değişkenlere ait korelasyon, ortalama ve standart sapma değerleri yer almaktadır. Tablo 3'e göre; yardımseverlik $(\mathrm{r}=-0,112 ; \mathrm{p}<0,05)$, yasalar ve kodlar $(\mathrm{r}=-0,108$; $\mathrm{p}<0,05)$, kurallar $(\mathrm{r}=-0,117$; $\mathrm{p}<0,05)$, verimlilik ( $\mathrm{r}=$ $-0,095 ; \mathrm{p}<0,05)$, şirket yararı etik iklimleri ile $(\mathrm{r}=$ $-0,011 ; p<0,05)$ işten ayrılma niyeti arasında zayıf yönlü ve negatif yönlü bir ilişki vardır. Kişisel ahlak ile işten ayrılma niyeti arasında ise pozitif yönlü ve zayıf bir ilişki $(r=0,108 ; p<0,05)$ vardır. Örgütsel özdeşleşme ile işten ayrılma niyeti arasında düşük ( $r=-0,293$; $p<0,01)$, kurallar etik iklimi ( $r=$ -0,058; $\mathrm{p}<0,01)$ ve kişisel çıkar etik iklimi ( $\mathrm{r}=-0,097$; $\mathrm{p}<0,05)$ arasında negatif yönlü ve zayıf bir ilişki tespit edilmiştir. Bununla birlikte diğer iklim türleri ve özdeşleşme arasında pozitif yönlü bir ilişki belirlenmiştir. 
Muharrem Tuna - Murat Yeşiltaş

Tablo 3. Araştırmada Kullanılan Değişkenlere Yönelik Ortalama, Standart Sapma ve Korelasyon Değerleri

\begin{tabular}{|c|c|c|c|c|c|c|c|c|c|c|c|c|}
\hline & $\bar{x}$ & s.s & 1 & 2 & 3 & 4 & 5 & 6 & 7 & 8 & 9 & 10 \\
\hline IAN & 2,57 & 1,15 & 1 & & & & & & & & & \\
\hline Yardımseverlik & 3,49 & ,90 &,$- 112^{*}$ & 1 & & & & & & & & \\
\hline Yasa ve Kodlar & 3,94 & ,74 &,$- 108^{*}$ &, $329^{* *}$ & 1 & & & & & & & \\
\hline Kişisel Ahlak & 3,10 & ,94 &, $108^{*}$ & ,053 & ,055 & 1 & & & & & & \\
\hline Kurallar & 4,19 & ,74 &,$- 117^{*}$ &, $233^{\star *}$ &, $576^{\star *}$ &, 043 & 1 & & & & & \\
\hline Örgüt Yararı & 3,35 & ,83 &,- 011 &, $142^{\star *}$ &, $374^{* *}$ &, $225^{\star *}$ &, $232^{* *}$ & 1 & & & & \\
\hline Verimlilik & 4,19 &, 72 &,$- 095^{\star}$ &, $320^{* *}$ &, $544^{\star *}$ &, $102^{*}$ &, $504^{* *}$ &, $229^{* *}$ & 1 & & & \\
\hline Kişisel Çıkar & 3,20 & ,96 &, $202^{* *}$ &,- 009 & ,061 &, $224^{\star *}$ & ,079 &, $183^{* *}$ & ,076 & 1 & & \\
\hline Özdeşleşme & 3,48 &, 94 &,$- 293^{* *}$ &, $133^{\star *}$ &, $301^{\star *}$ &,- 058 &, $252^{* *}$ &, $189^{* *}$ &, $183^{\star *}$ &,$- 097^{*}$ & 1 & \\
\hline Yabancılaşma & 2,67 & ,97 &, $527^{\star *}$ &,$- 141^{* *}$ &,$- 178^{\star *}$ &, $278^{\star *}$ &,$- 153^{\star *}$ &, $103^{*}$ &,$- 192^{\star *}$ &, $369^{* *}$ &,$- 244^{\star *}$ & \\
\hline
\end{tabular}

* Korelasyon 0,05 düzeyinde anlamlıdır (1-tailed).

** Korelasyon 0,01 düzeyinde anlamlıdır (1-tailed).

Araştırmada yardımseverlik etik iklimi ( $\mathrm{r}=$ $-0,141 ; \mathrm{p}<0,01)$, yasa ve kodlar etik iklimi $(\mathrm{r}=-0,178$; $\mathrm{p}<0,01)$, kurallar etik iklimi $(\mathrm{r}=-0,153 ; \mathrm{p}<0,01)$ ve verimlilik etik iklimi $(r=-0,192 ; \mathrm{p}<0,01)$ ile yabancılaşma arasında negatif yönlü ve zayıf bir ilişki tespit edilmiştir. Bununla birlikte kişisel ahlak ( $\mathrm{r}=$ 0,278; $p<0,01)$, kişisel çıkar $(r=0,369 ; p<0,01)$ etik iklimleri ile işe yabancılaşma arasında düşük, şirket yararı etik iklimi ile işe yabancılaşma arsında düşük $(r=0,103 ; p<0,01)$ ve işten ayrılma niyeti ile yabancılaşma arasında orta yönlü ve pozitif ilişki tespit edilmiştir.

\section{Ölçüm Modeli}

Hipotezlerin testine yönelik olarak LISREL 8.8 ile yapısal eşitlik modeli kullanılmıştır. Çalışmada Anderson ve Gerbing'in (1988) ikili yaklaşımı çerçevesinde öncelikle modelin doğrulanması yöntemine başvurulmuştur. Araştırmada model test edilmeden önce doğrulayıcı yaklaşıma uygun olarak ölçme aracının iyi uyum değerlerine sahip olup olmadığ incelenmiştir. Genellikle modelle verilerin birbirine uygunluğunun değerlendirilmesinde kullanılan ölçme aracı olarak modelin ölçme indisleri kullanılmaktadır (Schermelleh-Engel, Moosbrugger ve Müller 2003: 55). Analiz sonucunda model indisleri incelendiğinde ki-kare değeri $X^{2}=1845,94$ olarak tespit edilmiştir. Ölçme modeline yönelik ikinci adımda, normlaştırılmış ki-kare değeri hesaplanmıştır $\left(\mathrm{df}=900 ; \mathrm{p}=0,000 ; \mathrm{X}^{2} / \mathrm{sd}=\right.$ $(2,05 \leq, 3)$. Hipotez edilen modeli uyum değerlendi- rilmesinde bazı indisler kullanılmaktadır. Bunlar; RMSEA=0,052; $\mathrm{SRMR}=0,062 ; \mathrm{CFI}=0,94 ; \mathrm{NNFI}=$ 0,93 'tür. Bu değerler alanyazında yer alan ve kabul edilebilir değerler içindedir (Schermelleh-Engel vd. 2003: 52; Schumacker ve Lomax 2004: 82).

\section{Yapısal Eşitlik Modeli Sonuçları ve Hipotez Testi Sonuçları}

Önerilen model, otel işletmelerinde alt kademede çalışan 385 kişiye uygulanan anketlerden elde edilen verilerle test edilmiştir. Yapısal eşitlik modeli alan yazında yer alan ve önerilen iyi uyum değerlerine ulaşmıştır $\left(X^{2}=1863,34 ; \mathrm{df}=908 ; X^{2} /\right.$ $\mathrm{df}=2,05$; RMSEA $=0,052 ; \mathrm{CFI}=0,94 ; \mathrm{NNFI}=0,93$; $\mathrm{SRMR}=0,064)$. Tablo 4 'te yer alan standardize parametre yol katsayıları ise tüm modelin yol analizi sonuçlarını göstermektedir. Buna göre; yardımseverlik $(\alpha=-0,01 ; p>0,05)$, yasa ve kodlar $(\alpha=0,15$; $p>0,05)$, kurallar $(\alpha=0,11 ; p>0,05)$, örgüt yararı $(\alpha=$ $0,14 ; p>0,05)$ ve verimlilik $(\alpha=-0,22 ; p>0,05)$ etik iklimlerinin yabancılaşma üzerinde önemli bir etkisi tespit edilememiştir. Bu nedenle $\mathrm{H}_{1 \mathrm{a}}, \mathrm{H}_{1 \mathrm{~b}}, \mathrm{H}_{1 \mathrm{~d}}, \mathrm{H}_{1 \mathrm{e}}$ ve $\mathrm{H} 1_{\mathrm{f}}$ hipotezleri desteklenmemiştir. Kişisel ahlak $(\alpha=0,20 ; p<0,01)$ ve kişisel çıkar $(\alpha=0,38 ; p<0,01)$ etik iklimlerinin yabancılaşma üzerinde anlamlı bir etkisi tespit edilmesi nedeniyle $\mathrm{H}_{1 \mathrm{c}}$ ve $\mathrm{H}_{1 \mathrm{~g}}$ hipotezleri desteklenmiştir.

Çalışmada; yardımseverlik ( $\alpha=0,01 ; p>0,05)$, yasa ve $\operatorname{kodlar}(\alpha=0,20 ; p>0,05)$, kişisel ahlak $(\alpha=-0,03$; $p>0,05)$, kurallar $(\alpha=0,15 ; p>0,05)$, örgüt yararı ( $\alpha$ $=0,12 ; p>0,05)$ ve verimlilik $(\alpha=-0,04 ; p>0,05)$ etik 
Tablo 4. Hipotez Testi Sonuçları

\begin{tabular}{lccr}
\hline Hipotezler & $S P$ & $t$ değeri ${ }^{b}$ & Hipotez Testi \\
\hline H1a Yardımseverlik $\rightarrow$ Yabancılaşma & -0.01 & $-0,096$ & Desteklenmedi \\
\hline H1b Yasa ve Kod $\rightarrow$ Yabancılaşma & $-0,15$ & -1.06 & Desteklenmedi \\
\hline H1c Kişisel Ahlak $\rightarrow$ Yabancılaşma & 0,20 & 3.11 & Desteklendi \\
\hline H1d Kurallar $\rightarrow$ Yabancılaşma & 0,01 & 0,15 & Desteklenmedi \\
\hline H1e Örgüt Yararı $\rightarrow$ Yabancılaşma & 0,14 & 1,65 & Desteklenmedi \\
\hline H1f Verimlilik $\rightarrow$ Yabancılaşma & $-0,22$ & $-1,80$ & Desteklenmedi \\
\hline H1g Kişisel Çıkar $\rightarrow$ Yabancılaşma & 0,38 & 5,58 & Desteklendi \\
\hline H2a Yardımseverlik $\rightarrow$ Özdeşleşme & 0,01 & 0,10 & Desteklenmedi \\
\hline H2b Yasa ve Kod $\rightarrow$ Özdeşleşme & 0,20 & 1,32 & Desteklenmedi \\
\hline H2c Kişisel Ahlak $\rightarrow$ Özdeşleşme & $-0,03$ & $-0,43$ & Desteklenmedi \\
\hline H2d Kurallar $\rightarrow$ Özdeşleşme & 0,19 & 1,90 & Desteklenmedi \\
\hline H2e Örgüt Yararı $\rightarrow$ Özdeşleşme & 0,12 & 1,26 & Desteklenmedi \\
\hline H2f Verimlilik $\rightarrow$ Özdeşleşme & $-0,04$ & $-0,35$ & Desteklenmedi \\
\hline H2g Kişisel Çıkar $\rightarrow$ Özdeşleşme & $-0,19$ & $-2,91$ & Desteklendi \\
\hline H3 Yabancılaşma $\rightarrow$ IAN & 0,51 & 8,01 & Desteklendi \\
\hline H4 Özdeşleşme $\rightarrow$ IAN & $-0,22$ & $-4,17$ & Desteklendi \\
\hline
\end{tabular}

a:Standardize Yol Katsayısı

b: $p<0,01$

iklimlerinin özdeşleşme üzerinde anlamlı etkisi tespit edilememiştir. Bu nedenle $\mathrm{H}_{2 \mathrm{a}}, \mathrm{H}_{2 \mathrm{~b}}, \mathrm{H}_{2 \mathrm{c}}, \mathrm{H}_{2 \mathrm{~d}}$, $\mathrm{H}_{2 \mathrm{e}}$ ve $\mathrm{H}_{2 \mathrm{f}}$ hipotezleri desteklenmemiştir. Araştırmada kişisel çıkar etik iklimi ile özdeşleşme arasında negatif yönlü ve anlamlı bir etkisi tespit edilmiş $(\alpha=-0,19 ; p<0,01)$ ve $\mathrm{H}_{2 g}$ hipotezi desteklenmiştir.

$\mathrm{Bu}$ çalışmada beklenildiği gibi yabancılaşma ile işten ayrılma niyeti arasında pozitif yönlü ve anlamlı bir etki tespit edilmiştir $(\beta=0,51 ; p<0,01)$. Benzer şekilde özdeşleşme ile işten ayrılma niyeti arasında da negatif bir etkiye rastlanmıştır $(\beta=-0,22$; $\mathrm{p}<0,01)$. Bu sonuçlar doğrultusunda $\mathrm{H}_{3}$ ve $\mathrm{H}_{4}$ hipotezleri desteklenmiştir.

\section{SONUÇ}

Bu çalışmada etik iklimin; işten ayrılma niyeti, örgütsel özdeşleşme ve işe yabancılaşma üzerindeki etkileri araştırılmıştır. Bu amaçla Antalya ve Ankara illerinde beş yıldızlı otel işletmeleri çalışanlarına yönelik bir araştırma yapılmış ve etik iklim türlerinin diğer değişkenler üzerindeki etkilerini inceleyen bir çalışma gerçekleştirilmiştir. Çalışmada öne çıkan sonuçlar arasında beklenildiği üzere, yabancılaşma ile işten ayrılma niyeti arasında po- zitif yönlü bir ilişki tespit edilmesi yer almaktadır. Yabancılaşma "durumsal olarak gelişen" bir kavramdır. Dolayısıyla işyerindeki şartların yabancılaşmanın gelişmesinde etken olduğunu belirtmek yerinde olacaktır (Banai vd. 2004: 377). Sonuçları itibariyle de yabancılaşmanın işten ayrılmaya neden olduğu söylenebilir.

Araştırmada, özdeşleşme ile işten ayrılma niyeti arasında negatif yönlü bir ilişki olduğu belirlenmiştir. Bu sonuçtan hareketle, özdeşleşmeyi bireylerin işten ayrılma niyetini açılayan psikolojik bir süreç olarak değerlendirmek mümkündür. Bir başka ifadeyle, elde edilen sonuç bireylerin psikolojik olarak işleriyle bir bağlarının kalmamasının işten ayrılmaya etki ettiğini göstermesi bakımından önemlidir. Birey örgütüne ne kadar fazla bağlıysa, işyerinde kalma niyeti de o kadar fazla olacaktır. Böyle bir durumda daha düşük işgören devir hızı ortaya çıkacaktır (Allen ve Meyer 1990). Çalışmada ortaya çıkan bu sonuç alan yazında birçok çalışmayla da kanıtlanmıştır (Cole ve Bruch 2006; Öz ve Bulutlar 2009).

Araştırmada egoizm etik belirleyicisini temsil eden kişisel çıkar etik iklimi ile örgütsel özdeşleme 
arasında negatif yönlü bir ilişki tespit edilmiştir. Bu sonuç doğrultusunda örgütlerde kişisel çıkarların yaygınlaşmasının, bireylerin örgütte bilişsel ayrılığı etkilediğini ifade etmek doğru olacaktır. Benzer şekilde araştırmada, egoist temelli etik iklim türlerinin yaygınlaşmasının işe yabancılaşma üzerinde de etkileri olduğu tespit edilmiştir.

\section{Araştırmanın Yönetsel Katkısı}

Araştırmada kişisel çıar etik iklim türünün yabancılaşmayı olumlu yönde etkilediği sonucuna ulaşılmıştır. Bu durum örgüt içinde egoist temelli kişisel çıkar ikliminin yaygın olmasının bireyin anlamsızlaşmasına, normsuzlaşmasına veya güçsüzlük yaşamasına neden olduğu sonuçlarını doğurabilmektedir. Bu sonuç ayn zamanda yönetim kademelerinde bulunanların evrensel veya yerel (örgütsel) düzeyde bazı standartlar geliştirmesi, örgüt içinde normların yaygınlaştırılması veya yol haritası olarak nitelendirilecek etik kodların oluşturması gerektiği sonucunu da ortaya çıkarmaktadır. Benzer şekilde çalışmada kişisel çıkar etik iklimi ile özdeşleşme arasında negatif bir ilişkinin çıkmasının da bireysel değerlerin ön planda tutulduğu örgütlerde özdeşleşme sorunu yaşandığını göstermektedir.

Araştırmada ortaya çıkan bir başka önemli sonuç, örgütsel özdeşleşmenin işten ayrılma niyeti üzerindeki negatif yönlü etkisidir. Bu sonuçtan hareketle, yöneticilerin ilk olarak işgören seçiminden başlamak üzere bireylerin değerleri ile örgüt değerlerinin uyumlu olması (kişi-örgüt uyumu) hususunu dikkate alarak işgören seçimi yapmasının gerekli olduğu söylenebilir. Bireyin değerlerinde ve örgüt değerinde uyumsuzluk olması, kişinin özdeşleşme sorunu yaşamasına neden olmakta, bu da işten ayrılma niyetine etki etmektedir.

Araştırma sonuçlarına göre; yabancılaşma düzeyi ile işten ayrılma niyeti arasında doğrusal bir ilişki vardır. Alan yazında Develioğlu ve Tekin'in (2012) çalışması incelendiğinde bir yıldan az süre aynı işletmede çalışanların daha fazla yabancılaşma yaşadığı, buna karşın 10 yıldan fazla aynı işletmede çalışanların ise daha az yabancılaşma yaşadığı tespit edilmiştir. Bu durumda, çalışanların mesleklerine duymuş oldukları saygının artmasına ve bireylerin işlerinde daha fazla kontrol sahibi olmalarına yönelik çeşitli güçlendirici adımların atılması yerinde olacaktır.

\section{Sınırılıklar ve Gelecek Çalışmalara Yönelik Öneriler}

Çalışmada birkaç sınırlılık ön plana çıkmaktadır. Araştırma ilk olarak Ankara ve Antalya illerinde bulunan beş yıldızlı otel işletmelerine yöneliktir. $\mathrm{Bu}$ anlamda çalışmanın sadece bu illere yönelik genellenmesi söz konusudur. Aynı zamanda beş yıldızlı otel işletmelerinin yönetim tarzı itibariyle daha profesyonel yönetim sergiledikleri göz önüne alındığında, diğer belgeli işletmelere de çalışmanın uygulanması yerinde olacaktır.

Çalışma turizm sektörüne yönelik bir çalışma olmakla birlikte, sadece konaklama işletmelerini kapsamaktadır. Benzer bir çalışmanın, seyahat işletmeleri ve yiyecek içecek işletmeleri üzerinde de uygulanarak tüm sektörü kapsayacak biçimde tekrarlanması ve uygulanması yerinde olacaktır.

Çalışma, farklı modellemelerle tekrar denenebilir veya gelecekte de benzeri sonuçlar incelenerek güncellenebilir. Çalışmada aracı değişken olarak kullanılan özdeşleşme ve yabancılaşma, pozitif örgütsel davranışlar içinde yer alan proaktif davranışlar, örgütsel vatandaşlık davranışları ve işe adanma gibi değişkenlerle de tekrar test edilebilir. Dolayısıyla gelecekteki çalışmalar etik iklim ve işten ayrılma niyeti arasındaki etkileşime pozitif örgütsel davranışlardan hangisinin etki ettiği ortaya çıkarılabilir.

\section{KAYNAKÇA}

Allen, N. ve Meyer J. P. (1990). The Measurement and Antecedents of Affective, Continuance and Normative Commitment to the Organization, Journal of Occupational Psycho$\log y, 63: 1-18$.

Altunışık, R., Coşkun, R., Bayraktaroğlu, S., ve Yıldırım, E. (2005). Sosyal Bilimlerde Araştırma Yöntemleri SPSS Uygulamalı. (Geliştirilmiş 4.Baskı). Sakarya: Sakarya Kitabevi.

Ambrose, M. L., Arnaud, A. ve Schminke, M. (2008). Individual Moral Development and Ethical Climate: The Influence of Person-Organization Fit on Job Attitudes, Journal of Business Ethics, 77: 323-333.

Anderson, J. C. ve Gerbing, D.W. (1988). Structural Equation Modeling in Practice: A Review and Recommended TwoStep Approach, Psychological Bulletin, 103 (3): 411-423.

Appelbaum, S. H., Deguire, K. J. ve Lay, M. (2005). The Relationship of Ethical Climate to Deviant Workplace Behaviour, Corporate Governance, 5 (4): 43-55.

Banai, M., Reisel, W. D. ve Probst, T. M. (2004). A Managerial and Personal Control Model: Perceptions of Work Alienation and Organizational Commitment in Hungary, Journal of International Management, 10: 375-392.

Barnett, T. ve Vaicys, C. (2000). The Moderating Effect of Individuals Perceptions of Ethical Work Climates on Ethical Judgments and Behavioral Intentions, Journal of Business Ethics, 27: 351-367. 
Bulutlar, F. ve Öz, E.Ü. (2009). The Effects of Ethical Climates on Bullying Behaviour in the Workplace, Journal of Business Ethics, 86: 273-295.

Cho, S., Johanson, M. M. ve Guchait, P. (2009). Employees Intent to Leave: A Comparison of Determinants of Intent to Leave Versus Intent to Stay, International Journal of Hospitality Management, 28: 374- 381.

Cole, M. S. ve Bruch, H. (2006). Organizational Identity Strength Identification, and Commitment and their Relationships to Turnover Intention: Does Organizational Hierarchy Matter?, Journal of Organizational Behaviour, 27: 585-605.

Cotton, J. L. ve Tuttle, J. M. (1986). Employee Turnover: A MetaAnalysis and Review with Implications for Research, The Academy of Management Review, 11 (1): 55-70.

Cullen, J. B., Parboteeah, K. P. ve Victor, B. (2003). The Effects of Ethical Climates on Organizational Commitment: A TwoStudy Analysis, Journal of Business Ethics, 46: 127-141.

Cullen, J. B., Victor, B. ve Stephens, C. (1989). An Ethical Wheather Report: Assessing the Organizastion's Ethical Climates, Organizational Dynamics, 18 (2): 50-62.

DeConnick, J. (2011). The Effects of Ethical Climate on Organizational Identification, Supervisory Trust, and Turnover among Salespeople, Journal of Business Research, 64: 617-624.

DeConnick, J. (2010). The Influence of Ethical Climate on Marketing Employees' Job Attitudes and Behaviors, Journal of Business Research, 63: 384-391.

Develioğlu, K. ve Tekin, Ö.A. (2012). Otel Çalıșanlarının Yabancılaşma Düzeyinin Demografik Özellikler Kapsamında İncelenmesi, Uluslararası Alanya İşletme Fakültesi Dergisi, 4 (3): 121-128

DiPietro, R. B. ve Pizam, A. (2008). Employee Alienation in the Quick Service Restaurant Industry, Journal of Hospitality $\mathcal{E}$ Tourism Research, 32 (1): 22-39.

Dutton, J. E., Dukerich, J. M. ve Harquail, C. V. (1994). Organizational Images and Member Identification, Administrative Science Quarterly, 39: 239-263.

Elçi, M. ve Alpkan, L. (2009). The Impact of Perceived Organizational Ethical Climate on Work Satisfaction, Journal of Business Ethics, 84: 297-311.

Elsbach, K. D. ve Bhattacharya, C. B. (2001). Defining Who You are by What You're Not: Organizational Disidentification and the National Rifle Association, Organization Science, 12 (4): 393-414.

Epitropaki, O. ve Martin, R. (2005). The Moderating Role of Individual Differences in the Relation Between Transformational/Transactional Leadership Percepitions and Organizational Identification, The Leadership Quarterly, 16: 569-589.

Fritz, J. M. H., Arnett, R. C. ve Concet, M. (1999). Organizational Ethical Standarts and Organizational Commitment, Journal of Business Ethics, 20: 289-299.

Hall, D. T., Schneider, B. ve Nygren, H. T. (1970). Personel Factor in Organizational Identification, Administrative Science Quareterly: 176-191.

Haslam, S. A., Eggins, R. A. ve Reynolds, K. J. (2003). The ASPIRe Model: Actualizing Social and Personel Identity Resources to Enhance Organizational Outcomes, Journal of Occupational and Organizational Psychology, 76 (1): 83-113.

Hirschfeld, R. R. ve Feild, H. S. (2000). Work Centrality and Work Alienation: Distinct Aspects of a General Commitment to Work, Journal of Organizational Behavior, 21: 789-800.
Jung, J. ve George, R. T. (2012). Understanding the Influence of Polychronicitiy on Jop Statisfaciton aünd Turnover Intertion: A Study of Non-Supervisory Hotel Employees, International Journal of Hospitality Management, 31: 588-595.

Jung, H. S., Nankung, Y. ve Yoon, H. H. (2010). The Effects of Employees' Business Ethical Value on Person-Organization Fit and Turnover Intent in the Foodservice Industry, International Journal of Hospitality Managemenet, 29: 538-546.

Kalaycı, Ş. (2005). SPSS Uygulamalı Çok Değişkenli İstatistik Teknikleri. Ankara: Asil Yayıncılık.

Kaplan, M. (2010). Otel İşletmelerinde Etiksel İklim ve Örgütsel Destek Algılamalarının Örgütsel Bağl1lık Üzerindeki Etkisi: Kapadokya Örneği (Yayınlanmamış Doktora Tezi). Selçuk Üniversitesi Sosyal Bilimler Enstitüsü, Konya.

Katrinli, A., Atabay, G., Günay, G. ve Güneri, B. (2009). Exploring the Antecedents of Organizational Identification: The Role of Job Dimensions, Individual Characteristics and Job Involvement, Journal of Nursing Management, 17: 66-73.

Kılıç, K. C. (2010). Bireysel ve Örgütsel Değerler Arasındaki Uyumun Çalışanların İş Davranışlarına Etkileri Üzerine Ampirik Bir Çalışma, Ç.Ü. Sosyal Bilimler Enstitüsü Dergisi, 19 (1): 20-35.

Kim, N. (2012). Employee Turnover Intention Among Newcomes in Travel Industry, International Journal of Tourism Research, 16 (1): 56-64.

Küçükusta, D. (2007). Konaklama İşletmelerinde İş-Yaşam Dengesinin Çalışma Yaşamı Kalitesi Üzerindeki Etkisi (Yayınlanmamış Doktora Tezi). Dokuz Eylül Üniversitesi, S.B.E., İzmir.

Lemmergaard, J. ve Lauridsen, J. (2008). The Ethical Climate of Danish Firms: A Discussion and Enhancement of the Ethical-Climate Model, Journal of Business Ethics, 80: 653-675.

Lopez, T. B., Babin, B. J. ve Chung, C. (2009). Perceptions of Ethical Work Climate And Person-Organization Fit Among Retail Employee in Japan and the US: A Cros-Cultural Sacle Validation, Journal of Business Research, 62: 594-600.

Mael, F. ve Ashforth, B. E. (1992). Alumni and Their Alma Mater: A Partial Test of the Reformulated Model of Organizational Identification, Journal of Organizational Behavior, 13: 103-123.

Maddi S. R, Kobasa S. C. ve Hoover M. (1979). An Alienation Test. Journal of Humanistic Psychology, 19 (4): 73- 76.

Martin, K. D. ve Cullen, J. B. (2006). Continuities and Extensions of Ethical Climate Theory: A Meta-Analytic Review, Journal of Business Ethics, 69: 175-194.

Mignonac, K., Herrbach, O. ve Guerrero, S. (2006). The Interactive Effects of Perceived External Prestige and Need for Organizational Identification on Turnover Intentions, Journal of Vocational Behavior, 69: 477-493.

Mulki, J. P., Jaramillo, J. F., ve Locander, W. B. (2009). Critical Role of Leadership on Ethical Climate and Salesperson Behaviors, Journal of Business Ethics, 86: 125-141.

Nair, N. ve Vohra, N. (2009). Developing a New Measure of Work Alienation, Journal of Workplace Rights, 14 (3): 293-309.

Ögüut, A. ve Kaplan, M. (2011). Otel İşletmelerinde Etiksel İklim Algılamaları ile Örgütsel Bağlılık Arasındaki İlişkinin Analizi: Kapadokya Örneği, Dumlupınar Üniversitesi Sosyal Bilimler Enstitüsü Dergisi, 30: 191-206. 
Öz, E. Ü. ve Bulutlar, F. (2009). Alg1lanan Kurumsal İtibar ve Kurumdan Ayrılma Niyeti Arasındaki İlişkide Bir Ara Değişken Olarak Özdeşleşmenin Rolü, Yönetim Araştırmalar Dergisi, 9 (1): 35-52.

Özbek, M. F. (2011). Örgüt İçerisindeki Güven ve İşe Yabanc1laşma İlişkisinde Örgüte Uyum Sağlamanın Aracı Rolü, Süleyman Demirel Üniversitesi İktisadi ve İdari Bilimler Fakültesi Dergisi, 16 (1): 231-248.

Parboteeah, K. P., Chen, H. C., Lin, Y. T., Chen, I. H., Lee, A. Y. P. ve Chung, A. (2010). Establishing Organizational Ethical Climates: How Do Managerial Practices Work?, Journal of Business Ethics, 97 (4): 599-611.

Peterson, D. K. (2002). The Relationship Between Unethical Behavior and the Dimensions of the Ethical Climate Questionnaire, Journal of Business Ethics, 41: 313-326.

Riketta, M. (2005). Organizational Identification: A Meta Analysis, Journal of Vocational Behavior, 66: 358-384.

Rothwell, G. R. ve Baldwin, J. N. (2006). Ethical Climates and Contextual Predictors of Whistle-Blowing, Review of Public Personnel Administration, 26: 216-244.

Sarros, J. C., Tanewski, G. A.,Winter, R. P., Santora, J. C. ve Densten, I. L. (2002). Work Alienation and Organizational Leadership, British Journal of Management, 13 (4): 285-304.

Schermelleh-Engel, K., Moosbrugger, H. ve Müller, H. (2003). Evaluating the Fit of Structural Equation Models: Tests of Significance and Descriptive Goodness-of-Fit Measures, Methods of Psychological Research, 8 (2): 23-74.

Schumacker, R. E. ve Lomax, R. G. (2004). A Beginner's Guide to Structural Equation Modeling. İkinci Baskı. New Jersey: Lawrence Erlbaum Associates.

Schminke, M., Arnaud, A. ve Kuenzi, M. (2007). The Power of Ethical Work Climates, Organizational Dynamics, 36 (2): 171-186.

Schminke, M., Ambrose, M. L. ve Neubaum, D. O. (2005). The Effect of Leader Moral Development on Ethical Climate and Employee Attitudes, Organizational Behavior and $\mathrm{Hu}$ man Decision Processes, 97: 135-151.

Seeman, M. (1959). On the Meaning of Alienation, American Sociological Review, 24 (6): 783-791.

Seeman, M. (1967). On the Personal Consequences of Alienation in Work, American Sociological Review, 32 (2): 272-285.

Sims, W. J. (2007). Antecedents of Labor Turnover in Australian Alpine Resort, Journal of Human Resources in HospitalityETourism Research, 6(2): 1-26.

Smith, H. J., Thompson, R. ve Iacovou, C. (2009). The Impact of Ethical Climate on Project Status Misreporting, Journal of Business Ethics, 90: 577-591.

Sulu, S., Ceylan, A. ve Kaynak, R. (2010). Work Alienation as a Mediator of the Relationship between Organizational Injustice and Organizational Commitment: Implications for Healthcare Professionals, International Journal of Business and Management, 5 (8): 27-38.

Şencan, H. (2005). Sosyal Davranışsal Ölçümlerde Güvenilirlik ve Geçerlilik. Ankara: Seçkin Yayıncılık.

Şimşek, M. Ş., Çelik, A., Akgemci, T. ve Fettahlıŏlu, T. (2006). Örgütlerde Yabancılaşmanın Yönetimi Araştırması, Selçuk Üniversitesi Sosyal Bilimler Enstitüsü Dergisi,15: 569-587.

Tuna, M. (2007). Personel Devir Analizi: Ankara'da Yer Alan Y1ldızlı Otel İşletmelerinde Bir Uygulama, Anatolia Turizm Araştırmaları Dergisi, 18 (1): 45-52.
Tüzün, İ. K. ve Çağlar, İ. (2009). Investigating the Antecedents of Organizational Identification, Doğuş Üniversitesi Dergisi, 10 (2): 284-293

Tüzün, İ. K. (2006). Örgütsel Güven, Örgütsel Kimlik ve Örgütsel Özdeşleşme İlişkisi: Uygulamalı Bir Çalışma (Yayımlanmamış Doktora Tezi). Gazi Üniversitesi Sosyal Bilimler Enstitüsü, Ankara.

Ünsar, A. S. ve Karahan, D. (2011). Yabancılaşmanın İşten Ayrılma Eğilimine Etkisini Belirlemeye Yönelik Bir Alan Araştırması, Sosyal ve Ekonomik Araştırmalar Dergisi,15 (21): 361-379.

Valentine, S., Godkin, L. ve Lucero, M. (2002). Ethical Context, Organizational Commitment, and Person- Organization Fit, Journal of Business Ethics, 41: 349-360.

VanDick, R., Christ, O., Stellmacher, J., Wagner, U., Ahlswede, O., Grubba, C., Hauptmeier, M., Höhfeld, C., Moltzen, K. ve Tissington, P. A. (2004). Should I Stay or Should I Go? Explaining Turnover Intentions with Organizational Identification and Job Satisfaction, British Journal of Management, 15: 351-360.

VanDick, R. ve Wagner, U. (2002). Social Identification among School Teachers: Dimensions, Foci, and Correlates, European Journal of Work and Organizational Psychology, 11 (2): 129- 149.

VanKnippenberg, D. ve Sleebos, E. (2006). Organizational Identification Versus Organizational Commitment: SelfDefination, Social Exchange and Job Attitudes, Jounal of Organizational Behavior, 27: 571-584.

VanKnippenberg, D. (2000). Work Motivation and Performance: A Social Identity Perspective, Aplied Psychology: An International Review, 49: 357-371.

VanSandt, C. V., Shepard, J. M. ve Zappe, S. M. (2006). An Examination of the Relationship between Ethical Work Climate and Moral Awerness, Journal of Business Ethics, 68: 409-432.

Vardi, Y. (2001). The Effects of Organizational and Ethical Climates on Misconduct at Work, Journal of Business Ethics, 29: 325-337.

Victor, B. ve J. B. Cullen. (1988). The Organizational Bases of Ethical Work Climates, Administrative Science Quarterly, 33: 101-125.

Victor, B. ve Cullen, J. B. (1987), A Theory and Measure of Ethical Climate in Organizations, Research in Corporate Social Performance and Policy, 9: 51-71.

Wan-Huggins, V. N., Riordan, C. M. ve Griffeth, R. W. (1998). The Development and Longitudinal Test of a Model of Organizational Identification, Journal of Applied Social Psychology, 28 (8): 724-749.

Wayne, S. J., Shore, L. M. ve Linden, R. C. (1997). Perceived Organizational Support and Leader Member Exchange: A Social Exchange Perspective, Academy of Management Journal, 40 (1): 82-111.

Wimbush, J. C., Shepard, J. M. ve Markham, S. E. (1997). An Empirical Examination of the Relationship between Ethical Climate and Ethical Behavior from Multiple Levels of Analysis, Journal of Business Ethics, 16: 1705-1716. 